\title{
ECONOMIC EVALUATION OF INVESTMENT ACTIVITY OF AGRICULTURAL ENTERPRISES IN THE UKRAINE
}

\author{
Svitlana Savitska, $\mathrm{PhD}^{1}$; Pavlina Fugelo, $\mathrm{PhD}^{2}$
}

Faculty of Economics, State Agrarian and Engineering University in Podilya

\begin{abstract}
The article specifies that intensive development of the economy can be achieved by attracting and effectively using investment resources. Based on the indicator of the level of investment sufficiency, it was established that, in the period under review, the level of investment adequacy in the country is less than the established 'threshold' value, which indicates a shortage of investment funds. The study analysed the dynamics of investment attraction in agriculture. It was found that the main source of financing for investment is own funds of enterprises and organizations. However, they are too insufficient to ensure the intensive development of the economy. An analysis of growth dynamics of the total volume of investment in agricultural enterprises per 100 ha of agricultural land and their financial provision was carried out. Research showed that the increase in the value of fixed assets is more intensive than the increase in the inflow of investment in fixed assets, which indicates additional sources of growth in the value of fixed assets. It was noted that the potential sources of investment resources should be the funds of foreign investors, which currently stand at an extremely low growth level. A number of negative factors influencing the process of attracting foreign direct investment were identified. The main current requirements of the Ukraine in the process of integration into the world economic space, is the formation of a mechanism of investment activity, an important component of which is the mechanism of investment provision.
\end{abstract}

Keywords: investment, investment activity, agricultural enterprises

JEL codes: E22, Q14

\section{INTRODUCTION}

The period 1991-2000, which was characterized by an almost complete cessation of investment activity in agriculture, led to destructive processes: a decrease in the productivity of the industry, deterioration of the material and technical base, deterioration of the state of land resources, deterioration of the financial and production indicators of agricultural enterprises, etc. Lack of financial resources is a major problem in the reform of agriculture. Therefore, the establishment of a stable investment process is becoming significant.

\section{THEORETICAL BACKGROUND}

Issues of investment development are extremely relevant today, which is why they are at the centre of attention of scientists and economists, in particular M. Odnoroh, O. Feier, N. Patyka, R. Chornyi, V. Klochan, I. Bezpiata. The analysis of available research

${ }^{1}$ Correponding author: Schevchenko 13, Kamianets-Podilskyi, Ukraine, ovcharss15@gmail.com, +38 (097) 9474299

${ }^{2}$ Correponding author: Schevchenko 13, Kamianets-Podilskyi, Ukraine, ole18@meta.ua, +38 (097) 3270066 
makes it possible to assert the relevance of this problem, and therefore requires further consideration.

\section{MATERIALS AND METHODS}

In the process of research a set of general scientific and special methods of scientific knowledge was used, namely: abstract-logical and dialectical - for theoretical generalization and formulation of conclusions as well as monographic and statistical - in analysing the current state of investment activity of agricultural enterprises. The information base of the study consisted of the reporting data of the State Statistics Service of the Ukraine, publications on the topic of research by leading national and foreign scientists, Internet resources and results of own research.

\section{RESULTS AND DISCUSSION}

The economy status of the agricultural sector can be evaluated by the nature of processes taking place in the investment sphere. It is a definite indicator pointing to the general situation within the country (Odnoroh, 2015). The level of investment adequacy to ensure economic development is determined by compliance with the rate of investment in fixed assets in relation to GDP, a satisfactory value of which should be $25 \%$ (Feier, 2016) For the analysed period 2013-2017, the level of investment in the Ukrainian economy is considerably less than a certain value, and amounted to $14 \%$ in $2014,13.8 \%$ in 2015 and $12.2 \%$ of GDP in 2016. This indicates a significant shortage of investment resources in fixed assets and an inability to provide the necessary material and technical basis for the needs of the economy and can be interpreted as a low interest of investors in investing in the Ukrainian economy.

Let us analyse the investment activity of Ukrainian enterprises in 2013-2017 (Table 1). Thus, in 2014, the lowest activity of investors was observed, attracting only UAH 219.4 billion in agriculture. However, in the following years, the volume of investment dynamically increased and, in 2017, amounted to UAH 448.5 billion. Due to types of assets, most investment is made in tangible assets: $2013-96.0 \%$, 2014 - 96.6\%, 2015 - 93.3\%, 2016 - 96.7\%, 2017
- $96.3 \%$ of total volume. In 2017 , of the total volume of investment in tangible assets, an enormous part was accounted for by machinery, equipment and inventory - UAH 154,721.7 million (34.5\%). For engineering facilities - UAH 78,563.5 million (17.5\%), for non-residential buildings - UAH 65,605.2 million $(14.6 \%)$. The least investment resources were allocated to land - UAH 1,994.0 million (0.5\%) (State Statistics Service of Ukraine, 2017b).

The main source of financing capital investment is own funds of enterprises and organizations, due to which $68.04 \%$ of the total volume was disbursed. At the same time, the dynamics of changes in the structure of the sources indicate an increase in this share, in recent years. And this, in turn, actually testifies to the closed nature of economic recovery and the strong dependence of the state of investment in the country on the profits of enterprises and organizations, which is hardly supported by state or credit resources. The share of loans from banks and other loans in the total volume of investment is insignificant, reaching $15.3 \%$ in $2013,10 \%$ in $2014,7.6 \%$ in 2015 , and $8 \%$ in 2017 , respectively. The great share of loans was used to ensure the current activity of business entities, and not investment activities. This means that, in the Ukraine, banks fail to act as the driving force in the redistribution of financial resources for investment purposes. Since 2014, there was a slight upward trend in the share of state budget expenditure for financing of capital investments as a whole, from $1.2 \%$ in 2014 to $3.4 \%$ in 2017 . At the same time, the share from local budgets grew from $2.7 \%$ in 2013 up to $9.3 \%$ in 2017 , which correlates with national decentralization policy, during which, among others, financial resources were transferred. The share of foreign investor funds is rather low (on average $2.5 \%$ ) and there is no significant impact on the overall state of investment activity in the Ukraine (State Statistics Service of Ukraine, 2017b).

In 2017, enterprises and organizations absorbed UAH 448.5 billion at the expense of all sources of financing of capital investment, which is $25 \%$ more than the volume of capital investment for the corresponding period 2016. A significant share of capital investment was absorbed by machinery, equipment and inventory and vehicles - accounting for $47.9 \%$ 
Proceedings of the 2018 International Scientific Conference 'Economic Sciences for Agribusiness and Rural Economy' No 1, Warsaw, 7-8 June 2018, pp. 303-308

Table 1. Indicators of investment dynamics in the Ukraine

\begin{tabular}{|c|c|c|c|c|c|c|c|c|c|c|}
\hline \multirow[b]{2}{*}{ Specification } & \multicolumn{2}{|c|}{2013} & \multicolumn{2}{|c|}{2014} & \multicolumn{2}{|c|}{2015} & \multicolumn{2}{|c|}{2016} & \multicolumn{2}{|c|}{2017} \\
\hline & 丞: & $\partial^{\circ}$ & 跑兽 & $0^{\circ}$ & $\underset{\mathrm{S}}{\mathrm{S}}$ & $\partial^{\circ}$ & 跑总 & $a^{\circ}$ & 跑: & $a^{0}$ \\
\hline Capital investments total & 267.7 & 100 & 219.4 & 100 & 273.1 & 100 & 359.2 & 100 & 448.5 & 100 \\
\hline Capital investment in tangible assets & 257.1 & 96.0 & 212.0 & 96.6 & 254.7 & 93.3 & 347.4 & 96.7 & 432.1 & 96.3 \\
\hline Capital investment in intangible assets & 10.6 & 4.0 & 7.4 & 3.4 & 18.4 & 6.7 & 11.8 & 3.3 & 16.4 & 3.7 \\
\hline
\end{tabular}

\begin{tabular}{|l|c|c|c|c|c|c|c|c|c|c|}
\hline \multicolumn{10}{|c|}{ Capital investment by sources of financing } \\
\hline State budget funds & 6.5 & 2.4 & 2.7 & 1.2 & 6.9 & 2.5 & 9.3 & 2.6 & 15.3 & 3.4 \\
\hline Local budget funds & 7.2 & 2.7 & 5.9 & 2.7 & 14.3 & 5.2 & 26.8 & 7.5 & 41.6 & 9.3 \\
\hline Own funds of enterprises and organizations & 170.7 & 63.8 & 154.6 & 70.5 & 184.4 & 67.5 & 248.8 & 69.3 & 310.1 & 69.1 \\
\hline Bank loans and other loans & 40.9 & 15.3 & 21.7 & 9.9 & 20.7 & 7.6 & 27.1 & 7.5 & 29.6 & 6.6 \\
\hline Foreign investors funds & 4.8 & 1.8 & 5.6 & 2.6 & 8.2 & 3.0 & 9.9 & 2.7 & 10.8 & 2.4 \\
\hline Funds for housing construction & 28.3 & 10.6 & 22.1 & 10.0 & 32.0 & 11.7 & 30.0 & 8.3 & 32.8 & 7.3 \\
\hline Other sources of funding & 9.2 & 3.4 & 5.2 & 2.4 & 5.6 & 2.1 & 5.1 & 1.4 & 12.9 & 1.9 \\
\hline
\end{tabular}

Source: State Statistics Service of Ukraine (2017b).

of all investment. UAH 41.4 billion of capital investment was directed at capital repairs of assets $(9.2 \%$ of the total volume).

The volume of investment in fixed capital of agriculture in 2017 became a record for the entire history of Ukrainian independence (UAH 63.4 billion), that is 1.3 times higher than the indicator for 2016 (UAH 49.66 billion) and 3-4 times - in 2013 (UAH 18.64 billion) (Table 2). It is believed that such a positive trend is due to the fact that investors positively assess

Table 2. Dynamics of capital investment in agriculture in the Ukraine

\begin{tabular}{|l|c|c|c|c|c|c|}
\hline Indicators & 2013 & 2014 & 2015 & 2016 & 2017 & Deviation \\
\hline $\begin{array}{l}\text { Investment in fixed capital of } \\
\text { agriculture, hunting and related services } \\
\text { (million UAH) }\end{array}$ & 18639.7 & 18388.1 & 29309.7 & 49660.0 & 63400.7 & +4476.1 \\
\hline $\begin{array}{l}\text { Indices of increase of investment into } \\
\text { fixed capital of agriculture, hunting and } \\
\text { related services (\%) }\end{array}$ & 99.6 & 98.6 & 159.4 & 169.4 & 127.6 & +28 \\
\hline $\begin{array}{l}\text { Share of investment in fixed capital of } \\
\text { agriculture, hunting and related services } \\
\text { from the total volume (\%) }\end{array}$ & 7.0 & 8.4 & 10.7 & 13.9 & 14.1 & +7.1 \\
\hline $\begin{array}{l}\text { Investment in fixed assets of agriculture, } \\
\text { hunting and related services per capita of } \\
\text { rural population (UAH) }\end{array}$ & 1308.1 & 1305.1 & 2211.0 & 3769.1 & 4838.9 & +3530.8 \\
\hline
\end{tabular}

Source: compiled by the authors on the basis State Statistics Service of Ukraine (2017b). 
the level of profitability of their investment in the future. Positive dynamics of investment growth indices throughout the study period are also observed.

Investment in agriculture, in the Ukraine, are mainly directed to increase fixed capital (in construction, purchase of equipment, etc.), which is reflected in the growth of indices of stock protection. In Figure 1 , the growth dynamics of total investment in agricultural enterprises per 100 ha of agricultural land and their financial provision can be seen.

From Figure 1, it is clearly visible that the increase in the value of fixed assets was more intensive than the increase in the inflow of investment in fixed assets, which indicates additional sources of growth in the value of fixed assets, including the influence of inflation processes, which significantly devalues money investment receipts and facilities.

In addition, one cannot ignore the accumulative nature of direct investment, which, before reaching a certain critical volume, is characterized by increasing returns.

An important aspect of the dynamics in Figure 1 is also an opportunity to identify the time lag of investment impact in fixed assets on value (often investment that comes in the base year, due to a long period of development, increase the value of fixed assets in the year following the base one) (Chornyi, 2013). Most clearly, such a lag can be traced back to 2015-2016, when a sharp increase in the inflow of investment in fixed assets of agricultural enterprises in 2015 led to an increase in the value of fixed assets of research facilities in 2016.
The attraction of financial resources of foreign investors is important for the development of a country's economy and agriculture, in particular (Table 3) In general, a positive trend in attracting foreign direct investment (FDI) is observed, though its growth is very low. Thus, the growth of FDI (from countries of the world in the Ukraine) to GDP in 2015 was $-1.6 \%$, in 2017 the figure rose to $0.7 \%$ at a threshold of $5 \%$. Such results are due to the fact that GDP grows faster than FDI volume. Along with a lack of activity of domestic investors, a significant threat to the economic security of the Ukraine is the monopolization of foreign capital of strategic sectors of the economy, as can be seen indirectly by an increase in the share of FDI (from the countries of the world) in GDP from 31.1 in 2013 to 51.9 in 2015.

In 2017, the share of FDI decreased to $33.7 \%$, which is 5 times higher than the threshold. The share of FDI in GDP per capita in 2017 was 5.1\% (State Statistics Service of Ukraine, 2017a). This means that for the time being, agricultural production remains an insufficiently attractive industry for a foreign investor seeking to get a return on investment in the shortest possible time. Therefore, what is more promising for them is not the production of agricultural products, but their processing.

The unfavourable investment climate in the Ukraine is the main reason for a lack of strategic foreign investment. It determines the expectations of strategic investors, especially in terms of attracting medium and large capital. What is more, there is an uncertainty about further cooperation from inves-

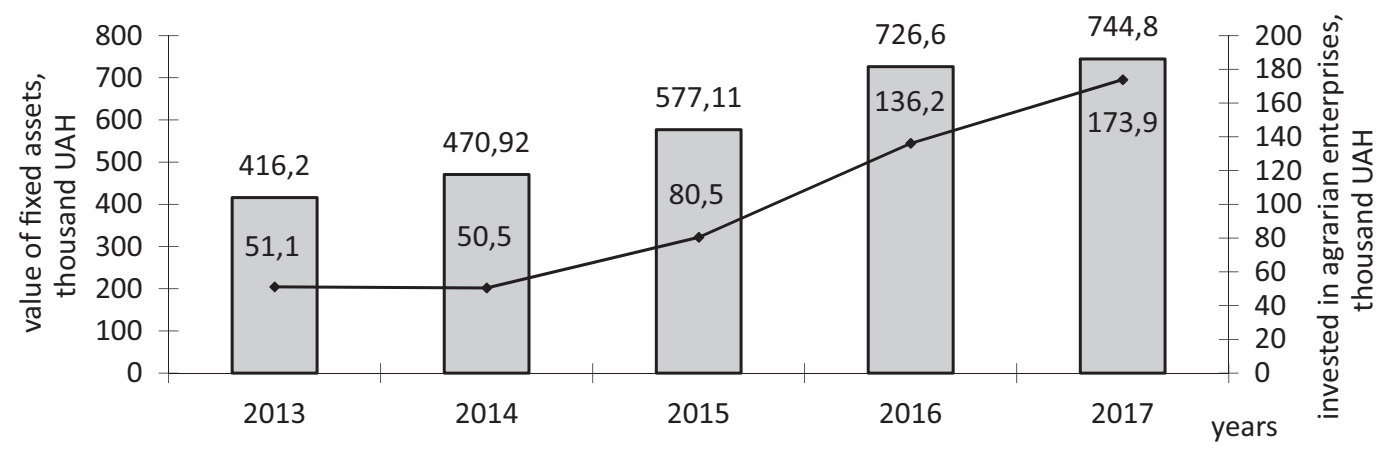

Figure 1. The ratio of investment in fixed assets to the value of fixed assets per 100 ha of agricultural land Source: compiled by the authors on the basis of State Statistics Service of Ukraine (2016). 
Proceedings of the 2018 International Scientific Conference 'Economic Sciences for Agribusiness and Rural Economy' No 1, Warsaw, 7-8 June 2018, pp. 303-308

Table 3. The dynamics of attracting foreign direct investment in the Ukraine

\begin{tabular}{|c|c|c|c|c|c|c|c|c|c|c|}
\hline \multirow{2}{*}{ Specification } & \multicolumn{5}{|c|}{ Investment volume (USD million) } & \multicolumn{5}{|c|}{$\begin{array}{c}\text { FDI in GDP (\%) } \\
\text { GDP growth in FDI (\%) }\end{array}$} \\
\hline & 2013 & 2014 & 2015 & 2016 & 2017 & 2013 & 2014 & 2015 & 2016 & 2017 \\
\hline $\begin{array}{l}\text { FDI from the world in } \\
\text { the economy of Ukraine }\end{array}$ & 51705.3 & 53704.0 & 40725.4 & 36154.5 & 37513.6 & $\begin{array}{c}31.1 \\
1.6\end{array}$ & $\begin{array}{c}44.7 \\
2.0\end{array}$ & $\begin{array}{c}51.9 \\
-15.6\end{array}$ & $\begin{array}{l}40.4 \\
-5.1\end{array}$ & $\begin{array}{c}33.7 \\
1.2\end{array}$ \\
\hline including agriculture & 717.8 & 776.9 & 617.0 & 502.2 & 586.2 & $\begin{array}{l}4.4 \\
0.4\end{array}$ & $\begin{array}{l}7.4 \\
0.6\end{array}$ & $\begin{array}{c}6.1 \\
-1.6\end{array}$ & $\begin{array}{c}4.7 \\
-1.1\end{array}$ & $\begin{array}{l}5.1 \\
0.7\end{array}$ \\
\hline $\begin{array}{l}\text { FDI from the EU } \\
\text { countries in the } \\
\text { economy of Ukraine }\end{array}$ & 41132.3 & 41032.8 & 31046.9 & 26405.6 & 26203.6 & $\begin{array}{c}22.9 \\
1.2\end{array}$ & $\begin{array}{l}40.2 \\
-0.1\end{array}$ & $\begin{array}{c}37.2 \\
-12.0\end{array}$ & $\begin{array}{l}29.6 \\
-5.2\end{array}$ & $\begin{array}{l}23.5 \\
-0.2\end{array}$ \\
\hline including agriculture & 505.8 & 552.9 & 431.7 & 336.8 & 402.4 & $\begin{array}{l}3.2 \\
0.1\end{array}$ & $\begin{array}{l}5.3 \\
0.6\end{array}$ & $\begin{array}{c}4.3 \\
-1.2\end{array}$ & $\begin{array}{c}3.2 \\
-0.9\end{array}$ & $\begin{array}{l}3.5 \\
0.6\end{array}$ \\
\hline
\end{tabular}

Source: compiled by the authors on the basis of State Statistics Service of Ukraine (2017a).

tors who have already invested in agriculture in the Ukraine (Patyka, 2018).

For most domestic agricultural enterprises, the source of investment is own funds (depreciation charges, profits), but for a more effective financial provision, it is necessary to apply raised funds as well as state and local budgets. After all, in conditions of proper state support, agrarian production has all the real opportunities to form sufficiently high macroeconomic indicators. What is important is the regulation of financial relations both at macro- and micro-levels. This problem is especially acute in the agrarian sector of the economy, since the corresponding conditions for its proper financing have not been created at a macro level. Tax and credit policy of the state undermine the opportunities for market development of agriculture, since tax burdens, lack of credit resources and lack of necessary subsidies do not allow it to develop effectively (Klochan and Bezpiata, 2016).

To accelerate the process of modernization of agriculture and the production of competitive products, governments of countries with developed market economies provide special preferential terms for investment lending. In particular, the interest rate of soft loans, depending on the conditions of agricultural production, is from 3.1 to $8.9 \%$. Privileged borrowers (cooperatives on the use of technology) enjoy a soft loan with an interest rate from 4.1 to $4.35 \%$.

One of the directions of activation of investment activity in agriculture abroad is the taxation mechanism, which includes: taxes on profits (net income) of companies; real estate, in particular land; invested capital, or an increase in fixed capital; additional costs; social insurance of hired labour; excises. In total, these taxes amount to $2.5-6 \%$ of all farm expenditures, of which about half are for two taxes: profits and real estate. Reforms of the tax system that provide incentives in developed countries promote active tax incentives for STPs requiring additional capital investment (Romanchuk, 2016).

As for the Ukraine, in order to improve environmental attractiveness for foreign investors, it is necessary to use world experience and gradually reduce the tax burden, adapting it to its specifics and development conditions. It is important to create such conditions that will make tax evasion impossible, and as a result, revenues to the state budget will increase.

For further improvement of investment activity in the Ukraine, the current issue requiring attention is the improvement of the legal and organizational framework in order to increase the capacity of mechanisms to ensure a favourable investment climate and the formation of a basis for the preservation and improvement of national economy competitiveness. 


\section{CONCLUSIONS}

An important condition for ensuring the effective development of agricultural enterprises is the availability of sufficient investment. As shown by the analysis for 2013-2017, the total volume of investment in agriculture is steadily growing. However, its growth is very low and does not even provide a simple reproduction of fixed assets. It is known that for macroeconomic stabilization, the country requires capital investment in the country's economy at a level of 19-25\% of GDP, while in 2017 , it was $15 \%$. Therefore, agricultural enterprises are acutely lacking financial resources and are constantly searching for both internal and external sources of investment. Due to the lack of funds in the budgets of central and regional authorities, the state virtually stands aside from investment processes. The share of foreign direct investment in agrarian production is extremely small and there is no significant impact on the state of its functioning and it does not contribute to the solution of development priorities. A significant threat to the economic security of the Ukraine is the monopolization of foreign capital by strategic sectors of the economy, which may be indirectly indicated by the growth in the share of FDI in 2017, which was up to $33.7 \%$. To attract investment, first of all, it is necessary to solve the problems of macroeconomic stabilization and activate all the levers of economic regulation of investment activity. Therefore, one of the necessary areas of action concerns an effective investment policy, aimed at largescale attraction of external sources of investment, a balanced state investment policy in agriculture and an increase in investment attractiveness as the main tasks of the Ukrainian government, with the aim of bringing the agrarian sector out of financial, material and technical crisis.

\section{REFERENCES}

1. Chornyi, R.V. (2013). Investment of agricultural enterprises in the conditions of development of market relations ( $\mathrm{PhD}$ thesis). Ternopil.

2. Feier, O.V. (2016). Investment support of local enterprises activity. Scientific Bulletin of Mukachevo State University, pp. 112-117.

3. Klochan, V.V., Bezpiata I.V. (2016). The structure of capital investments in agricultural production in Ukraine and the main sources of their formation. Bulletin DDAEU, 2, pp. 112-117.

4. Odnoroh, M.A. (2015). Peculiarities of investment activity in agricultural sector. Actual Problems of International Relations, 126, Part 2, pp. 108-115.

5. Patyka, N.I. (2018). Foreign investments in agriculture in Ukraine: the current state and the impact on its development. Investments: Practice and Experience, 5, pp. 26-31.

6. Romanchuk, Z.Z. (2016). Financial regulation of investment activity in Ukraine ( $\mathrm{PhD}$ thesis). Lviv.

7. State Statistics Service of Ukraine (2016). Regions of Ukraine. Part II. Kyiv.

8. State Statistics Service of Ukraine (2017a). Investment of External Economic Activity of Ukraine 2010-2016. Retrieved from: http://www.ukrstat.gov.ua [Accessed 31.05.2018].

9. State Statistics Service of Ukraine (2017b). Capital investments. Economic statistics. Retrieved from: http:// www.ukrstat.gov.ua [Accessed 31.05.2018]. 